\title{
Fermentative and bromatological characteristics of Piata palisadegrass ensiled with levels of meals from biodiesel industry
}

\author{
Características fermentativas e bromatológicas do capim-piatã \\ ensilado com níveis de farelos da indústria do biodiesel
}

\author{
Patrícia Soares Epifanio ${ }^{1 *}$; Kátia Aparecida de Pinho Costa ${ }^{2}$; Eduardo da Costa \\ Severiano $^{2}$; Welma Santos Cruvinel $^{1}$; Jose Carlos Bento ${ }^{3}$; Rozana Castro Perim ${ }^{1}$
}

\begin{abstract}
The goal of this study was to evaluate the fermentative and bromatological characteristics of Piata palisadegrass (Brachiaria brizantha cv. Piata) ensiled with levels of meals from biodiesel industry. The experiment was performed at the Federal Institute of Goias State, Campus Rio Verde. The experiment was a completely randomized design with four replications, in 4 x 4 factorial arrangement, being four meals (cotton, sunflower, soybean, and canola) and four levels of inclusion $(0,5,10$ and $15 \%)$. The results showed the oleaginous meals from biodiesel industry are indicated as additives for ensiling Piata palisadegrass, by improving the qualitative, nutritional and fermentative characteristics of the Piata palisadegrass silage. It is recommended the addition of $15 \%$ of the meals, since this level provides the best quality of silage. The soybean meal is the most effective to improve the silage quality, in comparison with the other additives.
\end{abstract}

Key words: Additive, Brachiaria brizantha, crude protein, fibrous materials

\section{Resumo}

Desenvolveu esse estudo com o objetivo de avaliar as características fermentativas e bromatológicas do capim-piatã ensilado com níveis de farelos da indústria do biodiesel. O experimento foi conduzido no Instituto Federal Goiano, Campus Rio Verde. O delineamento experimental utilizado foi o inteiramente casualizado, com quatro repetições, em esquema fatorial 4 x 4, sendo quatro farelos (algodão, girassol, soja e canola) e quatros níveis de adição $(0,5,10$ e 15\%). Os resultados demonstraram que os farelos da indústria do biodiesel pode ser indicado como aditivos para a ensilagem, por trazer melhorias nas características fermentativas, qualitativas e nutricionais da silagem de capim-piatã. Recomenda-se a adição do nível de $15 \%$ dos farelos, por proporcionar melhor qualidade da silagem. O farelo de soja mostrou-se mais eficiente para melhorar a qualidade da silagem, quando comparados com os outros aditivos.

Palavras-chave: Aditivo, Brachiaria brizantha, fração fibrosa, proteína bruta

\footnotetext{
${ }^{1}$ Discentes de Pós-graduação em Ciências Agrárias do Instituto Federal Goiano, Campus Rio Verde, Rio Verde, GO, Brasil. E-mail: patyepifanio@yahoo.com.br; welmacruvinel@hotmail.com; rozana.perim@gmail.com

${ }^{2}$ Profs. Pesquisadores, IF Goiano, Campus Rio Verde, Rio Verde, GO, Brasil. E-mail: katiazoo@hotmail.com; severianoec@ yahoo.com.br

${ }^{3}$ MSc. em Produção Vegetal, Universidade de Rio Verde, FESURV, Rio Verde, GO, Brasil. E-mail: josecarlos.bento@gmail.com

* Author for correspondence
} 


\section{Introduction}

Seasonality in forage production in the cerrado has been limiting for ruminant production, due to the low and unevenly distributed rainfall. This seasonality reduces the livestock production by significantly reducing the supply of forage during the dry period. Thus, the low quality and quantity of forage in this period require the use of practices to preserve the food produced in the rainy period, like the ensiling process (REGÔ et al., 2010).

Grasses of the genus Brachiaria have a high ability to produce forage with good nutritional value, and become one of the main forage options for intensive animal production. New cultivars have been continuously evaluated seeking a high productivity of plant and animal, in order to meet the requirements of the different production systems, with varied levels of technology. Thus, the Embrapa Beef Cattle released the Brachiaria brizantha cv. Piata, as an option for forage diversification (EMBRAPA, 2008). The researchers concluded that this grass has an excellent performance on soils of medium fertility, high regrowth rate and high production of forage with high nutritional value (EMBRAPA, 2008). Besides being used for grazing, it has nutritional characteristics suitable for making silage (COSTA et al., 2011).

Therefore, the high moisture at the ideal time for harvesting, the low content of soluble carbohydrates, and the high buffering capacity of this grass, inhibit an suitable fermentation process, hampering the production of a good quality silage (McDONALD; HENDERSON; HERON, 1991). These factors negatively influence the fermentation process, hindering the rapid decrease in $\mathrm{pH}$, allowing an undesirable secondary fermentation (EVANGELISTA et al., 2004).

Given these difficulties, the grass silage requires additives to provide good fermentation conditions. According to Santos et al. (2010), a good additive for silage of tropical grasses should present a high content of dry matter, disfavoring the growth of yeasts and contributing to lower losses of effluents, and with high nutritional level, palatability, and high content of soluble carbohydrates, as well as, easy handling, good availability in the market and low cost.

Among several alternatives of natural additives, the oleaginous meals from biodiesel production have emerged recently, such as meals of cotton, sunflower, soybean and canola. These meals are rich sources in energy and protein, representing an alternative to improve the silage quality, by amending the low contents of dry matter and contributing to a better fermentation of the silage. But little is known on the effect of these meals on fermentative and chemical parameters of the tropical grass silage. In this way, this study assessed the fermentative and chemical characteristics of Piata palisadegrass (Brachiaria brizantha cv. Piata) ensiled with levels of meals from biodiesel industry.

\section{Material and Methods}

The experiment was conducted in the Federal Institute of Goias State, Campus Rio Verde, 748 $\mathrm{m}$ altitude, $17^{\circ} 48^{\prime}$ south latitude and $50^{\circ} 55^{\prime}$ west longitude, from September 2010 to July 2011. The area of pasture used to produce the silage had 180 $\mathrm{m}^{2}$.

The soil was classified as distroferric Red Latosol (Oxisol), with $530 \mathrm{~g} \mathrm{~kg}^{-1}$ clay; $250 \mathrm{~g} \mathrm{~kg}^{-1}$ silt and $220 \mathrm{~g} \mathrm{~kg}^{-1}$ sand. The chemical characteristics of the soil at the layer $0-20 \mathrm{~cm}$, before planting were: $\mathrm{pH}$ in water: 5.6; $\mathrm{Ca}: 4.04 \mathrm{cmol}_{\mathrm{c}} \mathrm{dm}^{-3} ; \mathrm{Mg}: 2.0 \mathrm{cmol}_{\mathrm{c}}$ $\mathrm{dm}^{-3}$; Al: $0.0 \mathrm{cmol}_{\mathrm{c}} \mathrm{dm}^{-3} ; \mathrm{Al}+\mathrm{H}: 6.6 \mathrm{cmol}_{\mathrm{c}} \mathrm{dm}^{-3} ; \mathrm{K}$ : $65 \mathrm{mg} \mathrm{dm}^{-3}$; CTC: $7.05 \mathrm{cmol}_{\mathrm{c}} \mathrm{dm}^{-3}$; P: $8.07 \mathrm{mg} \mathrm{dm}^{-3}$; $\mathrm{Cu}: 3.7 \mathrm{mg} \mathrm{dm}^{-3}$; Zn: $1.8 \mathrm{mg} \mathrm{dm}{ }^{-3}$; V: 48.4\%; M.O: $35.6 \mathrm{~g} \mathrm{~kg}^{-1}$.

The area was prepared with harrowing followed by leveling. In the planting of forage it was applied $80 \mathrm{~kg} \mathrm{ha}^{-1} \mathrm{P}_{2} \mathrm{O}_{5}$, using the super triple phosphate. Then, the Piata palisadegrass was broadcast seeded with $9 \mathrm{~kg}$ viable pure seeds per hectare. 
The standardization cut was held at 40 days after planting, and the topdressing included $80 \mathrm{~kg} \mathrm{ha}^{-1}$ nitrogen and $40 \mathrm{~kg} \mathrm{ha}^{-1}$ potassium, as urea and potassium chloride, respectively.

The experiment was a completely randomized design with four replications, in $4 \times 4$ factorial arrangement, being four meals from biodiesel industry (cotton, sunflower, soybean, canola) and four levels of inclusion $(0,5,10$ and $15 \%)$. The brans were obtained by grinding the grains and passing through a $2 \mathrm{~mm}$ sieve. The addition levels were determined based on the natural Piata palisadegrass material.

For the ensiling process, the Piata palisadegrass was harvested at 45 days after maintenance fertilization, at $20 \mathrm{~cm}$ from ground level, using backpack brush cutter. Afterwards, the forage was minced into $10-30 \mathrm{~mm}$-particles, with a stationary shredder, and ground. Then, the material was homogenized with the meals, according to different levels determined, and stored in PVC experimental silo, with $10 \mathrm{~cm}$ diameter and $40 \mathrm{~cm}$ length. The specific mass of silo was $1.12 \mathrm{~kg} \mathrm{dm}^{3}$. The silage was compacted with iron pendulum and silos were sealed with PVC caps and adhesive tape to prevent the entry of air. Immediately after, they were stored at room temperature and protected from rain and sunlight.

After 60 days of fermentation, the silos were opened, discarding the top and bottom portions of each. The central portion was homogenized and placed into plastic trays. Part of the fresh silage after opening the silo was set apart to analyze the fermentation parameters, such as $\mathrm{pH}$, titratable acidity, and ammonia nitrogen in relation to total nitrogen $\left(\mathrm{N}-\mathrm{NH}_{3} / \mathrm{TN}\right)$. The determination of $\mathrm{pH}$ and titratable acidity of the silage was made using potentiometer after opening up the silos.

After this, the silage was split into two portions. The first was placed into plastic bags and frozen. For the determination of ammonia nitrogen $[\mathrm{N}$ -
$\left.\mathrm{NH}_{3}(\% \mathrm{TN})\right]$ the samples were thawed to extract the juice, with press (AOAC, 1980). The other part of about $1 \mathrm{~kg}$ was weighed and taken to a forced air oven at $55^{\circ} \mathrm{C}$ for 96 hours to determine the predrying matter. Later, the samples were ground in a Wiley mill, with $1 \mathrm{~mm}$-sieve, to be analyzed.

For chemical composition of the silages, it was determined the contents of dry matter (DM), crude protein (CP), neutral detergent fiber (NDF), acid detergent fiber (ADF), lignin, cellulose, hemicellulose, ether extract (EE), and ash, by method described by Silva and Queiroz (2002). The total carbohydrate (TCH) was obtained by the equation of Sniffen et al. (1992): TCH $=100-(\%$ $\mathrm{CP}+\% \mathrm{EE}+\%$ ash). The total digestible nutrient (TDN) was obtained through the NDF content, using the formula: \% TDN $=105.2-0.68(\% \mathrm{NDF})$, proposed by Chandler (1990).

For in vitro dry matter digestibility (IVDMD), the technique described by Tilley and Terry (1963) was adopted. This technique was adapted to the artificial rumen that was developed by $\mathrm{ANKON}^{\circledR}$ by using the "Daisy incubator" instrument from Ankom Technology. The ruminal liquid was collected from two fistulated male bovines with an average weight of $550 \mathrm{~kg}$. These animals were allowed to graze on Brachiaria brizantha cv. Marandu.

Before the ensiling process, the Piata palisadegrass and the meals were subjected to bromatological analysis, as shown in Table 1.

The data were subjected to analysis of variance that considered the addition levels of the additives and the interactions between these factors as sources of variation. These averages were compared by using the Tukey test with a probability of 5\% in the SISVAR 4.6 statistical software (FERREIRA, 2000). The additive levels were evaluated by regression analysis, from which the coefficient of determination was evaluated. The regression equations were generated from the graphs in Sigma Plot. 
Table 1. Bromatological composition of the Piata palisadegrass and meals of cotton, sunflower, soybean, and canola used to produce the silage.

\begin{tabular}{lccccc}
\hline \multicolumn{1}{c}{ Composition } & Piata palisadegrass & Cotton & Sunflower & Soybean & Canola \\
\hline DM (\%) & 18.4 & 90.1 & 91.1 & 88.7 & 89.0 \\
CP (\%) & 12.5 & 41.7 & 28.6 & 42.0 & 37.9 \\
NDF (\%) & 68.3 & 23.0 & 45.4 & 18.07 & 32.1 \\
ADF (\%) & 39.5 & 14.9 & 23.5 & 10.24 & 22.3 \\
Lig (\%) & 4.91 & 4.39 & 4.18 & 3.78 & 4.16 \\
Cel (\%) & 34.6 & 10.5 & 19.3 & 6.46 & 18.1 \\
Hemic (\%) & 28.8 & 8.1 & 21.9 & 7.83 & 9.8 \\
EE (\%) & 2.35 & 2.63 & 2.15 & 3.43 & 2.56 \\
Ash (\%) & 11.3 & 9.5 & 10.2 & 8.7 & 10.0 \\
TCH (\%) & 73.8 & 44.1 & 59.1 & 45.9 & 49.6 \\
TDN (\%) & 59.4 & 69.4 & 57.0 & 74.0 & 64.0 \\
IVDMD (\%) & 63.0 & 74.0 & 71.0 & 80.6 & 72.8 \\
\hline
\end{tabular}

DM- dry matter; CP- crude protein; NDF- neutral detergent fiber; ADF- acid detergent fiber; Lig- lignin; EE- ether extract; TCHtotal carbohydrates; TDN- total digestible nutrients; IVDMD - in vitro dry matter digestibility

Source: Elaboration of the authors.

\section{Results and Discussion}

The $\mathrm{pH}$, titratable acidity, N-NH3/TN, and DM, $\mathrm{EE}, \mathrm{MM}, \mathrm{TCH}, \mathrm{CP}, \mathrm{NDF}, \mathrm{ADF}$, lignin, cellulose, and hemicellulose content were influenced $(\mathrm{P}<0.05)$ by the additives, levels, and interaction between these factors (Tables 2, 3 and 4).

The $\mathrm{pH}$ is one of the major factors determining the proliferation and survival of microorganisms, besides being used as a quality parameter of the silage (AMARAL et al., 2007). There was a linear reduction of $\mathrm{pH}$ for sunflower and canola meals, with increasing levels of additives on ensiling and a quadratic effect for cotton and soybean meals, in which the minimum point was estimated at the levels of 13.5 and $11.6 \%$, respectively, indicating that additives were efficient to reduce the silage $\mathrm{pH}$. This result is related to the greater contents of DM at this level, since they have a high content of DM in relation to Piata palisadegrass (Table 1). According to Jobim et al. (2007), silage of materials with high moisture has high $\mathrm{pH}$ values (above 4.2). Thus, these results suggested a suitable fermentation of the silage mixtures, a desirable feature for the ensiling process. This allows inferring that by adding the meals from biodiesel industry, there is a suitable amount of soluble carbohydrates for the activity of lactic bacteria, which leads to lower $\mathrm{pH}$.

Evaluating the additives within each level, at the level zero the $\mathrm{pH}$ values were similar between the studied additives. At the levels of 5, 10 and 15\% the canola meal achieved the highest values of $\mathrm{pH}$, proving to be more effective for lowering the silage $\mathrm{pH}$, when compared with the other additives, with a reduction of 0.9 percentage units in relation to level zero, while the average of the other meals was 1.2 percent (Table 2).

Tomich et al. (2004) reported that $\mathrm{pH}$ between 3.8 and 4.2 are considered suitable to well preserved silages, once these $\mathrm{pH}$ values sufficiently limit the activity of proteolytic enzymes of the plant, and of enterobacteria and Clostridium, to preserve the material. Also, at $15 \%$ level, the soybean and sunflower meals presented the lowest $\mathrm{pH}$ values. Paziani et al. (2006) found a value of 4.7 when added millet meal to tanzania-grass silage. 
Table 2. Fermentative parameters of Piata palisadegrass ensiled with levels of additives.

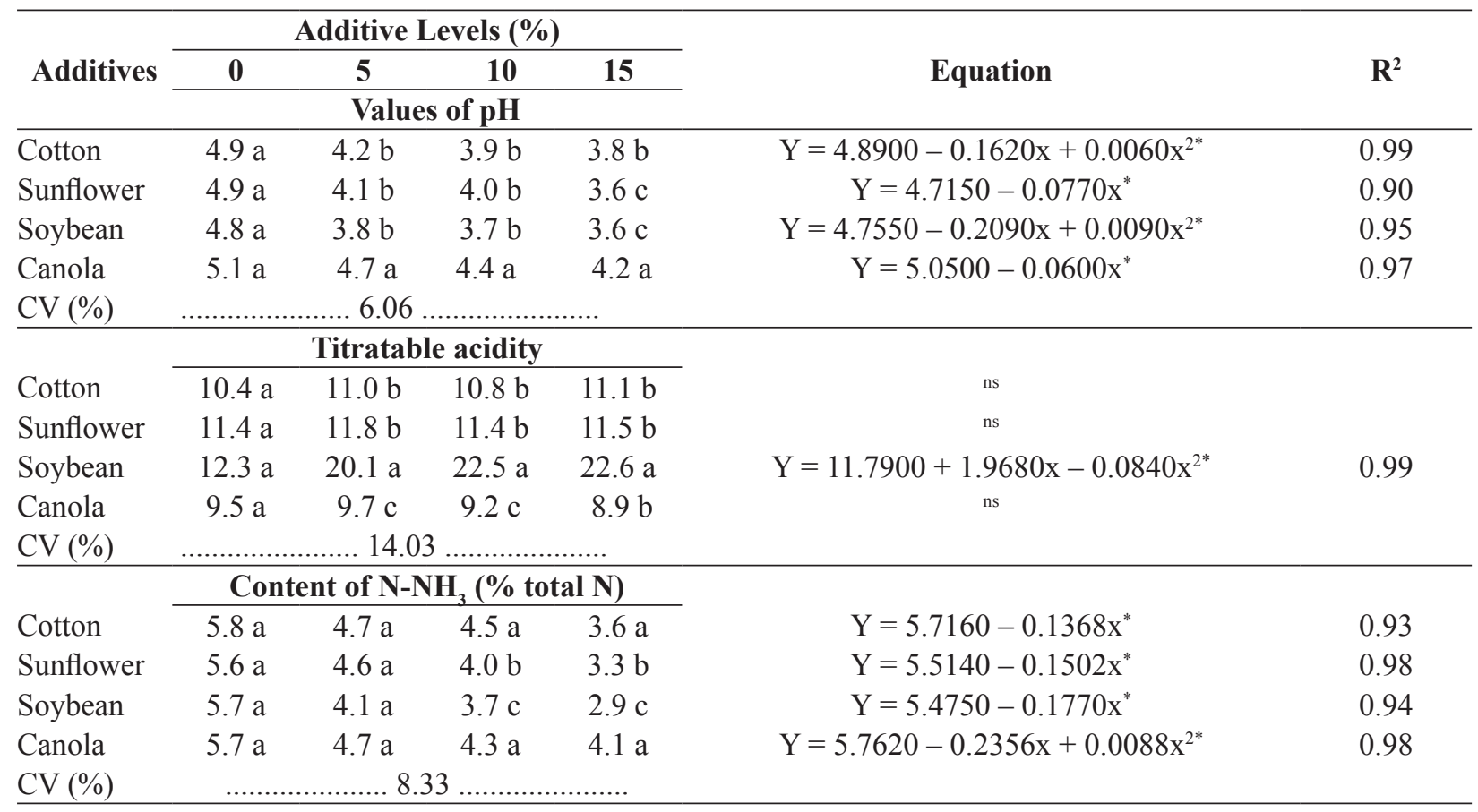

Means followed by different lower cases in the column (additive) are significantly different by Tukey's test $(\mathrm{P}<0.05)$. *significant at $5 \%$ level, ns $=$ non-significant at $5 \%$ level.

Source: Elaboration of the authors.

Only the soybean meal influenced the titratable acidity (Table 2), as added the additive levels to the silage, it increased quadratically, with a maximum at the level of $11.7 \%$, indicating an increase of 10.3 percent in relation to level zero. However, the meals of cotton and sunflower were not different from each other, and the canola meal promoted the lowest titratable acidity.

At the levels of 5 and $10 \%$, the soybean meal presented higher values of titratable acidity, and the canola meal, the lowest ones, differing from cotton and sunflower meals. At the $15 \%$ level, only the soybean meal was different from the others. Silva and Queiroz (2002) observed that the types of additives may interfere with the relationship between $\mathrm{pH}$ and lactic acid, and the titratable acidity indicates the general aspect of the fermentation quality of silages, influencing the taste, odor, color, and stability, by being directly related to the acids that determine the $\mathrm{pH}$, primarily lactic acid (NUSSIO; SIMAS; LIMA, 2001).
The content of $\mathrm{N}-\mathrm{NH}_{3} / \mathrm{TN}$ also indicates the silage quality and assists in characterizing the fermentation during the process. The lower this ratio, the lower the proteolysis of ensiled material and the better the silage quality (McDONALD; HENDERSON; HERON, 1991).

A linear decrease was found in $\mathrm{N}-\mathrm{NH}_{3} / \mathrm{TN}$ for cotton, sunflower and soybean meals as increased the additive levels in the silage. However for the canola meal there was a quadratic effect, in which the minimum point was estimated at the level of $13.3 \%$. The inclusion of $15 \%$ promoted a reduction of $2.2 ; 2.3 ; 2.7$ and 1.6 percent in relation to the non-addition of this meal, indicating a decrease in crude protein degradation. This is due to the higher content of DM and high $\mathrm{pH}$ at the level 15\%, which may reduce the bacteria activity, mainly of the genus Clostridium, which promote proteolysis and release of $\mathrm{N}-\mathrm{NH}_{3} / \mathrm{TN}$ during the ensiling process (TEIXEIRA et al., 2008). Nevertheless, the greater 
content of $\mathrm{N}-\mathrm{NH}_{3} / \mathrm{TN}$ in the silage without additives was due to the lower content of readily fermentable carbohydrates, the lower DM content and higher buffering capacity, typical of perennial grasses (LEONEL et al., 2009).

At levels zero and $5 \%$ the contents of $\mathrm{N}^{-\mathrm{NH}_{3}} /$ $\mathrm{TN}$ were similar between the meals examined. At the levels 10 and $15 \%$, the soybean meal presented the lowest content. But all the silages had values within the recommended range for a good quality silage (below 10\%). Even in the treatments without additives, the contents of $\mathrm{N}-\mathrm{NH}_{3} / \mathrm{TN}$ were acceptable, with values ranging from 5.62 to $5.88 \%$. These have remained below $10 \%$ indicating the good quality of the silage for this parameter, according to Tomich et al. (2004). This indicates that the fermentation did not result in excessive breakdown of protein into ammonia, and the amino acids are most of non-protein nitrogen (VAN SOEST, 1994).

Oliveira et al. (2010) found $\mathrm{N}-\mathrm{NH}_{3} / \mathrm{TN}$ between 24.0 and $58.0 \mathrm{~g} / \mathrm{kg}$ relative to $1^{\text {st }}$ and $56^{\text {th }}$ days of fermentation, respectively, when added 10\% of palm cake in the pupunha byproduct silage. Carvalho et al. (2008) evaluating the fermentative characteristics of elephant grass silage added with cocoa meal, observed a quadratic effect of the inclusion levels of the meal on $\mathrm{N}-\mathrm{NH}_{3} / \mathrm{TN}$ contents, with the minimum value $(2.83 \%)$ in the silage with $4.5 \%$ of cocoa meal.

The content of DM increased linearly with the levels of all meals in the silage (Table 3), showing the efficiency of these additives to absorb water inside the silo, improving thus the fermentation and silage quality. Brito et al. (2000) reported that the DM content of the silage is important to determine the type of predominant fermentation in the ensiling process.

At the level of $5 \%$, only the soybean differed from the other treatments with higher DM content. At the level of $15 \%$, DM content was similar between the meals of cotton, sunflower and soybean, only differing from canola meal, with highest value, increasing 9.8 percent in relation to the control (Table 3).

The addition of 8,16 and $24 \%$ of palm cake from biodiesel industry to Massai guineagrass silage promoted a great absorption of moisture, increasing linearly the DM content from $22.3 \%$ to $38.1 \%$ at the levels zero to $24 \%$, respectively (OLIVEIRA et al., 2011). By adding $15 \%$ of millet meal, Costa et al. (2011) registered increases in DM content from 20.5 to $28.4 \%$; from 21.9 to $31.5 \%$, and from 19.7 to $31.0 \% \mathrm{DM}$ for silages of Marandu, Piata and Xaraes palisadegrasses, respectively. In the same way, Gonçalves et al. (2007) evaluated the elephant grass silage added with cashew apple and achieved a remarkable increase in DM content, varying from $20.8 \%$ at level zero, to $33.8 \%$ by adding $20 \%$ of the additive.

The inclusion of additives promoted a positive linear increase in the content of $\mathrm{CP}$ of the silage, observed for all used meals. The addition of 15\% resulted in increasing $9.2 ; 8.7 ; 15.4$ and 9.2 percent when compared with the non-addition. This can be explained by two reasons: the first related to the higher CP content of the meals in relation to Piata palisadegrass, so that their addition improve the silage quality; the second owing to the higher DM contents of the meals at the level of $15 \%$, restricting the Clostridium activity, preserving thus the forage protein fraction (AGUIAR et al., 2001).

At levels 5, 10 and 15\% the sunflower and canola meals had the lowest CP contents, differing from soybean and cotton meals which promoted an expressive increase in CP content of the silage. This result is correlated with the $\mathrm{CP}$ content of the soybean meals $(42.0 \%)$ and cotton $(41.7 \%)$ in relation to the other meals. Zanine et al. (2010) observed the importance of working with additives with high $\mathrm{CP}$ content to improve the silage and provide better quality food. 
Table 3. Bromatological composition of Piata palisadegrass ensiled with levels of cotton, sunflower, soybean and canola meals.

\begin{tabular}{|c|c|c|c|c|c|c|}
\hline \multirow{3}{*}{ Additives } & \multicolumn{4}{|c|}{ Additive Levels (\%) } & \multirow{3}{*}{ Equation } & \multirow{3}{*}{$\mathbf{R}^{2}$} \\
\hline & $\mathbf{0}$ & 5 & 10 & 15 & & \\
\hline & \multicolumn{4}{|c|}{ Content of DM (\%) } & & \\
\hline Cotton & $17.1 \mathrm{a}$ & $18.4 \mathrm{~b}$ & $20.0 \mathrm{a}$ & $21.7 \mathrm{~b}$ & $Y=16.9900+0.3080 x^{*}$ & 0.99 \\
\hline Sunflower & $16.9 \mathrm{a}$ & $18.0 \mathrm{~b}$ & $19.6 \mathrm{a}$ & $21.4 \mathrm{~b}$ & $Y=16.7100+0.3020 x^{*}$ & 0.98 \\
\hline Soybean & $16.8 \mathrm{a}$ & $20.8 \mathrm{a}$ & $21.7 \mathrm{a}$ & $23.4 \mathrm{~b}$ & $Y=17.5700+0.4140 x^{*}$ & 0.91 \\
\hline Canola & $17.1 \mathrm{a}$ & $18.7 \mathrm{ab}$ & $20.9 \mathrm{a}$ & $26.9 \mathrm{a}$ & $Y=16.1600+0.6320 x^{*}$ & 0.90 \\
\hline \multirow[t]{2}{*}{ CV $(\%)$} & & $\ldots \ldots \ldots . .$. & $9 \ldots \ldots .$. & & & \\
\hline & \multicolumn{4}{|c|}{ Content of CP (\%) } & & \\
\hline Cotton & $7.9 \mathrm{a}$ & $14.6 \mathrm{a}$ & $18.4 \mathrm{a}$ & $20.8 \mathrm{a}$ & $Y=9.0500+0.8500 x^{*}$ & 0.95 \\
\hline Sunflower & $7.7 \mathrm{a}$ & $12.1 \mathrm{~b}$ & $14.2 \mathrm{~b}$ & $16.4 \mathrm{~b}$ & $Y=8.3700+0.5640 x^{*}$ & 0.96 \\
\hline Soybean & $7.8 \mathrm{a}$ & $15.5 \mathrm{a}$ & $21.1 \mathrm{a}$ & $23.2 \mathrm{a}$ & $Y=9.1300+1.0360 x^{*}$ & 0.94 \\
\hline Canola & $7.8 \mathrm{a}$ & $10.6 \mathrm{~b}$ & $12.7 \mathrm{c}$ & $17.0 \mathrm{~b}$ & $Y=7.6050+0.5910 x^{*}$ & 0.97 \\
\hline \multirow[t]{2}{*}{ CV (\%) } & $\ldots \ldots \ldots$ & $\ldots \ldots \ldots 1$ & $31 \ldots \ldots .$. & $\ldots \ldots \ldots$ & & \\
\hline & \multicolumn{4}{|c|}{ Content of EE $(\%)$} & & \\
\hline Cotton & $2.5 \mathrm{a}$ & $2.8 \mathrm{~b}$ & $3.8 \mathrm{a}$ & $4.1 \mathrm{~b}$ & $Y=2.4300+0.1160 x^{*}$ & 0.94 \\
\hline Sunflower & $2.7 \mathrm{a}$ & $4.2 \mathrm{a}$ & $4.4 \mathrm{a}$ & $5.2 \mathrm{a}$ & $\mathrm{Y}=2.9735+0.1547 \mathrm{x}^{*}$ & 0.90 \\
\hline Soybean & $2.8 \mathrm{a}$ & $3.3 \mathrm{~b}$ & $4.0 \mathrm{a}$ & $4.2 \mathrm{~b}$ & $\mathrm{Y}=2.8400+0.0980 \mathrm{x}^{*}$ & 0.96 \\
\hline Canola & $2.4 \mathrm{a}$ & $4.1 \mathrm{a}$ & $4.3 \mathrm{a}$ & $5.3 \mathrm{a}$ & $Y=2.6800+0.1810 x^{*}$ & 0.91 \\
\hline \multirow[t]{2}{*}{ CV $(\%)$} & $\ldots \ldots$. & $\ldots \ldots . .1$ & $3 \ldots \ldots$ & .......... & & \\
\hline & \multicolumn{4}{|c|}{ Content of MM (\%) } & & \\
\hline Cotton & $10.5 \mathrm{a}$ & $10.0 \mathrm{a}$ & $9.3 \mathrm{a}$ & $9.2 \mathrm{a}$ & $Y=10.4470-0.0876 x^{*}$ & 0.91 \\
\hline Sunflower & $11.2 \mathrm{a}$ & $10.1 \mathrm{a}$ & $9.6 \mathrm{a}$ & $8.5 \mathrm{~b}$ & $\mathrm{Y}=11.2170-0.1736 \mathrm{x}^{*}$ & 0.97 \\
\hline Soybean & $10.5 \mathrm{a}$ & $8.7 \mathrm{a}$ & $7.5 \mathrm{~b}$ & $6.9 \mathrm{~b}$ & $Y=10.2310-0.2408 x^{*}$ & 0.95 \\
\hline Canola & $11.0 \mathrm{a}$ & $8.2 \mathrm{a}$ & $8.0 \mathrm{~b}$ & $7.7 \mathrm{~b}$ & $\mathrm{Y}=10.9345-0.5711 \mathrm{x}+0.0243 \mathrm{x}^{2^{*}}$ & 0.94 \\
\hline \multirow[t]{2}{*}{ CV $(\%)$} & ......... & ........ 17 & t ............ & $\ldots \ldots .$. & & \\
\hline & \multicolumn{4}{|c|}{ Content of TCH (\%) } & & \\
\hline Cotton & $79.4 \mathrm{a}$ & $74.3 \mathrm{~b}$ & $70.9 \mathrm{~b}$ & $67.7 \mathrm{~b}$ & $Y=78.8810-0.7688 x^{*}$ & 0.98 \\
\hline Sunflower & $78.2 \mathrm{a}$ & $73.1 \mathrm{~b}$ & $71.8 \mathrm{~b}$ & $69.7 \mathrm{~b}$ & $Y=77.2590-0.5342 x^{*}$ & 0.91 \\
\hline Soybean & $78.6 \mathrm{a}$ & $73.0 \mathrm{~b}$ & $68.1 \mathrm{~b}$ & $66.5 \mathrm{~b}$ & $\mathrm{Y}=77.7940-0.8272 \mathrm{x}^{*}$ & 0.95 \\
\hline \multirow{2}{*}{$\begin{array}{l}\text { Canola } \\
\text { CV (\%) }\end{array}$} & $80.6 \mathrm{a}$ & $78.6 \mathrm{a}$ & $78.6 \mathrm{a}$ & $70.2 \mathrm{a}$ & $Y=80.1060+0.3372-0.0640 x^{2^{*}}$ & 0.91 \\
\hline & \multicolumn{4}{|c|}{ 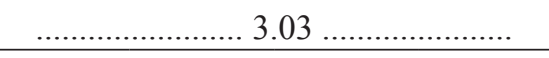 } & & \\
\hline
\end{tabular}

Means followed by different lower cases in the column (additive) are significantly different by Tukey's test $(\mathrm{P}<0.05)$. DM- dry matter; CP- crude protein; EE- ether extract; MM- mineral matter; TCH- total carboydrates

*significant at $5 \%$ level.

Source: Elaboration of the authors.

Likewise, Gonçalves et al. (2007) achieved increases in the CP content with cashew apple used in the silage of elephant-grass and Brachiaria decumbens and Paziani et al. (2006), with addition of millet meal to Tanzania guineagrass silage.

Moreover, the additives were effective to increase the EE content of the silage regardless the used meal, promoting a positive linear effect (Table 3). This increase is caused by higher EE content of the meals compared to the Piata palisadegrass (Table 1).

At the levels 0 and $10 \%$, the contents were similar between the meals. At the level of $5 \%$, cotton and soybean meals differed from the other meals, presenting lower EE content. At the level of $15 \%$, canola and sunflower meals presented the highest contents, compared to cotton and soybean. EE content of meals from agro-industries usually 
depends on the species used, seed quality, and method used to extract the oil, given the broad variation between the analyzed samples (OLIVEIRA et al., 2011).

Furthermore, regardless of additive and inclusion level, the EE content did not exceed $6-7 \%$ in the DM. According to NRC (2001), the total dietary fat should not exceed these values, since it may reduce the ruminal fermentation, fiber digestibility, and passage rate.

Rezende et al. (2002) studied the nutritional value of the elephant grass silage added with sunflower and verified an EE content of $7.49 \%$ in the silage added with $50 \%$ sunflower, which is explained by the participation of sunflower seed in the silage, with higher levels of inclusion.

Considering the mineral matter, there was a linear reduction for the meals of cotton, sunflower and soybean, with increasing levels in the silage. Nevertheless, for the canola meal, a quadratic effect was observed, where the minimum point was estimated at the level of $14.5 \%$.

When compared the additives within each level, the soybean and canola meals at $10 \%$ presented similar contents of mineral matter, being distinct from cotton and sunflower. But at the level of $15 \%$, only the cotton meal was different from the others. For all meals, the level zero presented the highest mineral matter contents due to the increased potential for losses in these treatments with inadequate fermentation, with losses of organic matter, increasing the relative participation of ash (mineral matter) in the DM (ASHBELL, 1995).

Oliveira et al. (2011) evaluated the inclusion of palm cake in the ensiling of Massai guineagrass and verified a negative linear trend of the mineral matter as a function of its levels in the silage, and for each $1 \%$ inclusion of cake, there was a reduction of 0.137 percent of mineral matter.

With the addition of the examined levels, there was a linear decrease in $\mathrm{TCH}$ content with increasing levels of cotton, sunflower and soybean meals in the silage, and a quadratic effect for canola meal, estimating a maximum value of $70.2 \%$ for level of $14.6 \%$. This decrease is related to the higher contents of CP and EE at the 15\% level. Sniffen et al. (1992) registered that high CP and EE contents can reduce the estimation of TCH content, due to the high content of these fractions.

At zero level, $\mathrm{TCH}$ content was similar between the meals. At the levels of 5, 10 and 15\%, the cotton, sunflower and soybean meals had similar results, differing from canola, which presented the highest content of TCH. Carvalho et al. (2007) evaluating elephant grass silage with cocoa meal, observed a linear reduction in TCG content, with a decrease of 0.22 percent for every unit of added meal. The same was observed by Andrade et al. (2010), who analyzed the elephant grass silage and verified a reduction of $9.21 \%$ in the content of $\mathrm{TCH}$ of cocoa meal in relation to other additives.

For NDF, a linear reduction was observed for cotton, sunflower and soybean meals, with increasing levels of additives. However, the canola meal led a quadratic decrease, reaching the minimum at the level of $14.3 \%$ (Table 4 ). The additives inclusion is important because the Piata palisadegrass has a high NDF content, and the partial replacement by the meals allowed the fiber dilution, promoting a reduction in the NDF content in the silage.

At the level zero, the content was similar between the meals. The levels of 5 and $10 \%$ indicated the canola meal with the highest NDF content, differing from other meals. At the $15 \%$ level, soybean and cotton meals presented lowest NDF content, proving to be more effective to reduce this fraction, which has more indigestible components. These results are assigned to the lowest fiber content in the soybean and cotton meals (Table 1) compared with sunflower and canola. Lima et al. (2002) reported that NDF content is important to improve the nutritional value of the forage, being an important parameter to define the forage quality, because the most fibrous food takes up space for longer time and limits the intake rate. 
The decrease in the NDF content was also found by Ribeiro et al. (2008), which added wheat meal in the silage of elephant grass, and by Costa et al. (2011) when added millet meal in the silage of marandu, xaraés and Piata palisadegrass.

The ADF content was also reduced with meals addition, with a linear decrease for increasing levels of cotton, sunflower and soybean in the silage, and a quadratic effect with the minimum point at the level of $14.0 \%$ for canola meal (Table 4 ). These results are owed to the low fiber content of the meals (Table 1). At the level 5\%, the lowest content was obtained for soybean meal. For level $10 \%$, only the canola meal was different from the others with the highest content. At the level zero and $15 \%$, the ADF content was similar between the meals.

Table 4. Fibrous fractions of Piata palisadegrass ensiled with levels of additives.

\begin{tabular}{|c|c|c|c|c|c|c|}
\hline \multirow{3}{*}{ Additives } & \multicolumn{4}{|c|}{ Additive levels (\%) } & \multirow{3}{*}{ Equation } & \multirow{3}{*}{$\mathbf{R}^{2}$} \\
\hline & $\mathbf{0}$ & 5 & 10 & 15 & & \\
\hline & \multicolumn{4}{|c|}{ Content of NDF (\%) } & & \\
\hline Cotton & $71.3 \mathrm{a}$ & $68.5 \mathrm{c}$ & $63.4 \mathrm{~b}$ & $58.4 \mathrm{~b}$ & $\mathrm{Y}=71.9700-0.8760 \mathrm{x}^{*}$ & 0.98 \\
\hline Sunflower & $71.1 \mathrm{a}$ & $69.9 \mathrm{bc}$ & $65.6 \mathrm{~b}$ & $62.3 \mathrm{a}$ & $Y=71.8300-0.6140 x^{*}$ & 0.96 \\
\hline Soybean & $71.0 \mathrm{a}$ & $69.5 \mathrm{bc}$ & $60.5 \mathrm{c}$ & $58.1 \mathrm{~b}$ & $\mathrm{Y}=71.9475-0.9555 \mathrm{x}^{*}$ & 0.91 \\
\hline Canola & $72.0 \mathrm{a}$ & $72.5 \mathrm{a}$ & $69.6 \mathrm{a}$ & $60.8 \mathrm{ab}$ & $\mathrm{Y}=71.8750+0.6650 \mathrm{x}-0.0930 \mathrm{x}^{2^{*}}$ & 0.99 \\
\hline \multicolumn{7}{|c|}{$\ldots \ldots \ldots \ldots \ldots . .2 .54 \ldots \ldots \ldots \ldots \ldots$} \\
\hline & \multicolumn{4}{|c|}{ Content of ADF (\%) } & & \\
\hline Cotton & $44.9 \mathrm{a}$ & $44.3 \mathrm{a}$ & $37.2 \mathrm{~b}$ & $33.9 \mathrm{a}$ & $\mathrm{Y}=46.0900-0.8020 \mathrm{x}^{*}$ & 0.91 \\
\hline Sunflower & $44.6 \mathrm{a}$ & $42.2 \mathrm{a}$ & $36.4 \mathrm{~b}$ & $32.8 \mathrm{a}$ & $\mathrm{Y}=45.1800-0.8240 \mathrm{x}^{*}$ & 0.97 \\
\hline Soybean & $44.4 \mathrm{a}$ & $38.7 \mathrm{~b}$ & $35.7 \mathrm{~b}$ & $32.3 \mathrm{a}$ & $Y=43.6700-0.7860 x^{*}$ & 0.97 \\
\hline Canola & $44.3 \mathrm{a}$ & $43.7 \mathrm{a}$ & $40.4 \mathrm{a}$ & $33.0 \mathrm{a}$ & $\mathrm{Y}=44.2300+0.2760 \mathrm{x}-0.0680 \mathrm{x}^{2^{*}}$ & 0.99 \\
\hline \multicolumn{7}{|c|}{ 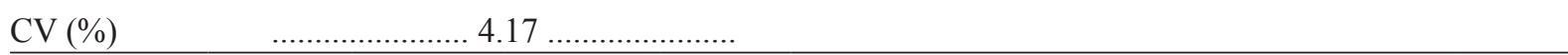 } \\
\hline & \multicolumn{4}{|c|}{ Content of Lignin (\%) } & & \\
\hline Cotton & $5.3 \mathrm{a}$ & $4.8 \mathrm{a}$ & $4.3 \mathrm{a}$ & $3.9 \mathrm{a}$ & $\mathrm{Y}=5.2800-0.0940 \mathrm{x}^{*}$ & 0.99 \\
\hline Sunflower & $5.2 \mathrm{a}$ & $4.7 \mathrm{a}$ & $4.2 \mathrm{a}$ & $3.3 \mathrm{~b}$ & $\mathrm{Y}=5.2800-0.1240 \mathrm{x}^{*}$ & 0.97 \\
\hline Soybean & $5.4 \mathrm{a}$ & $5.1 \mathrm{a}$ & $4.4 \mathrm{a}$ & $3.5 \mathrm{~b}$ & $\mathrm{Y}=5.5600-0.1280 \mathrm{x}^{*}$ & 0.95 \\
\hline Canola & $5.1 \mathrm{a}$ & $4.8 \mathrm{a}$ & $4.3 \mathrm{a}$ & $3.4 \mathrm{~b}$ & $\mathrm{Y}=5.1600-0.1080 \mathrm{x}^{*}$ & 0.95 \\
\hline \multicolumn{7}{|c|}{ 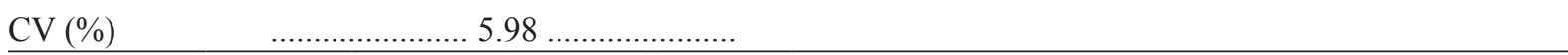 } \\
\hline \multicolumn{7}{|c|}{ Content of Cellulose (\%) } \\
\hline Cotton & $39.5 \mathrm{a}$ & $38.1 \mathrm{a}$ & $32.9 \mathrm{~b}$ & $29.9 \mathrm{a}$ & $\mathrm{Y}=39.9500-0.3100 \mathrm{x}-0.0260 \mathrm{x}^{2^{*}}$ & 0.93 \\
\hline Sunflower & $39.3 \mathrm{a}$ & $37.4 \mathrm{a}$ & $32.1 \mathrm{~b}$ & $29.4 \mathrm{a}$ & $Y=39.7500-0.7500 x+0.0020 x^{2^{*}}$ & 0.94 \\
\hline Soybean & $39.4 \mathrm{a}$ & $33.5 \mathrm{~b}$ & $32.0 \mathrm{~b}$ & $31.3 \mathrm{a}$ & $\mathrm{Y}=39.2200-1.2960 \mathrm{x}+0.0520 \mathrm{x}^{2^{*}}$ & 0.98 \\
\hline Canola & $39.2 \mathrm{a}$ & $38.9 \mathrm{a}$ & $36.0 \mathrm{a}$ & $29.3 \mathrm{a}$ & $Y=39.1400+0.3080 x-0.0640 x^{2^{*}}$ & 0.99 \\
\hline $\mathrm{CV}(\%)$ & & & & & & \\
\hline \multicolumn{7}{|c|}{ Content of Hemicellulose (\%) } \\
\hline Cotton & $28.3 \mathrm{a}$ & $26.1 \mathrm{~b}$ & $24.5 \mathrm{ab}$ & $24.1 \mathrm{bc}$ & $\mathrm{Y}=27.8800-0.2840 \mathrm{x}^{*}$ & 0.92 \\
\hline Sunflower & $29.5 \mathrm{a}$ & $28.2 \mathrm{a}$ & $27.7 \mathrm{a}$ & $26.3 \mathrm{a}$ & $\mathrm{Y}=29.4400-0.2020 \mathrm{x}^{*}$ & 0.97 \\
\hline Soybean & $30.2 \mathrm{a}$ & $26.3 \mathrm{~b}$ & $23.6 \mathrm{~b}$ & $22.8 \mathrm{c}$ & $Y=29.4600-0.4980 x^{*}$ & 0.92 \\
\hline Canola & $29.2 \mathrm{a}$ & $28.7 \mathrm{a}$ & $28.8 \mathrm{a}$ & $27.7 \mathrm{ab}$ & ns & \\
\hline $\mathrm{CV}(\%)$ & $\ldots \ldots$ & .......... 7. & & $\ldots \ldots \ldots .$. & & \\
\hline
\end{tabular}

Means followed by different lower cases in the column (additive) are significantly different by Tukey's test (P<0.05). NDF- neutral detergent fiber; ADF- acid detergent fiber; *significant at 5\% level, ns = non-significant at 5\% level.

Source: Elaboration of the authors. 
The ADF content observed in the silage added with 10 and $15 \%$ of meals was within the adequate range, once Nussio, Manzano and Pedreira (1998) reported that forages with ADF content around $40 \%$ or more have low intake and digestibility.

When added the palm cake in ensiling Massai guineagrass, Oliveira et al. (2011) found a linear reduction in the NDF and ADF content of the silage, and for each $1 \%$ of palm cake added, a reduction of 0.099 and 0.101 percentage units was achieved for the NDF and ADF.

Regarding the lignin content, Table 4 shows that the addition of levels caused a linear effect for all meals examined, with a reduction in lignin content as increased the levels of additives, and most expressive at the level of $15 \%$, due to the dilution effect of this fraction. These results are relevant to improve the silage quality, by providing a food with low lignin content, which is important because it is not a carbohydrate but an amorphous phenylpropanoid polymer with structural function, indigestible, and inhibits the plant digestibility (MARANHÃO et al., 2009). Van Soest (1994) stated that lignin has a great negative influence on degradation rate and effective degradability of cell wall of the forages, besides having silica and cutin.

At levels zero, 5 and $10 \%$ the lignin content was similar between the meals, but at the level 15\%, the influence of the additives was evidenced, and the cotton meal presented the highest content. This is due to the higher lignin content in the cotton meal (4.39\%).

Analyzing the Tanzania guineagrass, Ribeiro et al. (2008) observed that the lignin content decreased with the inclusion of wheat bran, pointing out that this additive made more digestible the silage. This result can be explained by the recalcitrant ability of the lignin, which is minimized, allowing a better use of the fiber by the microorganisms.

For cellulose content, the meals inclusion promoted a quadratic decrease with minimum point at the levels of $14.1 ; 13.9,14.5$ and $14.7 \%$, for cotton, sunflower, soybean and canola meals, respectively. Van Soest (1994) explained that cellulose is the most important structural portion of the cell wall; its availability varies from indigestible to completely digestible, depending on the lignification degree. The cellulose content remained between $20 \%$ and $40 \% \mathrm{DM}$, as recommended by Van Soest et al. (1994) in tropical forage.

Comparing the additives within each level, at the levels zero and $15 \%$, the cellulose content was similar between the meals (Table 4). Meanwhile, for the $5 \%$ level, the soybean level reached the lowest level and at the level of $10 \%$, only the canola meal was different from the others, with the highest cellulose content. Bernardino et al. (2005) evaluated the elephant-grass silage with different levels of coffee husk, and recorded an average content of cellulose of $38.5 \%$, showing that the addition of coffee husk had no influence on the cellulose content.

The hemicellulose content also was reduced with increasing levels of additives, with a linear decrease for cotton, sunflower and soybean meals. This can be explained by its hydrolysis, which according to McDonald, Henderson and Heron (1991) is caused by several factors, such as: enzymatic activity of the hemicellulose in the forage and produced by the bacteria, and the acid hydrolysis owed to the organic acids produced during the fermentation. In agreement with Hunt et al. (1993), the hemicellulose seems to be the main substrate for fermentation, after the use of soluble carbohydrates, with a possible degradation of $50 \%$ of the total in the original organic matter.

At the level zero, hemicellulose content was similar between the meals. At the level 5\%, lower contents were obtained with cotton and soybean meals. For the level 10\% only the soybean meal was different from sunflower and canola meals, and at $15 \%$ the soybean meal showed the lowest content of hemicellulose. Henderson (1993) reported that protein, amino acid, and organic acid contribute to the production of acids; however the hemicellulose 
fermentation is the major additional source of substrate.

Even with the variation between the levels within each additive, the present study showed that the content of hemicellulose obtained with the additives are according values recommended by McDonald, Henderson and Heron (1991) for grasses, ranging from 10 to $30 \%$ DM.

The in vitro dry matter digestibility (IVDMD) increased linearly for the meals of cotton and canola with increased levels of the meals in the ensiling process, and a quadratic effect, with the maximum point at the level $14.0 \%$ for sunflower, and $13.7 \%$ for soybean meal (Table 5). Comparing the level zero with the level $15 \%$, there was increase of 6.0 ; 9.1; 15.9 and 8.5 percent for cotton, sunflower, soybean and canola meals, respectively. This increased digestibility is probably associated with changes in the chemical composition of the fraction with a reduced NDF and ADF and of hemicellulose content, which certainly make available the carbohydrates readily digestible for ruminal microorganisms (FERNANDES et al., 2002).

Rezende et al. (2008) studied the elephant grass silage added with potato scraps and registered a linear increasing response $(58.2 ; 62.2 ; 66.2 ; 70.2$ and $74.2 \%$ ) for the IVDMD in relation to the inclusion of the levels $0,7,14,21$ and $28 \%$, respectively. Similar results were found by Rodrigues et al. (2007) with elephant-grass ensiled with citrus pulp, when they verified a linear increase in the IVDMD with increased addition of pulp in the silage.

Table 5. In vitro dry matter digestibility of the Piata palisadegrass ensiled with different levels of additives.

\begin{tabular}{lccccccc}
\hline \multirow{2}{*}{ Additives } & \multicolumn{4}{c}{ Additive levels (\%) } & & \multirow{2}{*}{ Equation } \\
\cline { 2 - 5 } & $\mathbf{0}$ & $\mathbf{5}$ & $\mathbf{1 0}$ & $\mathbf{1 5}$ & & $\mathbf{R}^{\mathbf{2}}$ \\
\hline Cotton & $54.0 \mathrm{a}$ & $55.5 \mathrm{~d}$ & $57.2 \mathrm{~d}$ & $60.0 \mathrm{c}$ & $\mathrm{Y}=53.7200+0.3940 \mathrm{x}^{*}$ & 0.97 \\
Sunflower & $53.7 \mathrm{a}$ & $60.7 \mathrm{~b}$ & $62.0 \mathrm{~b}$ & $62.8 \mathrm{~b}$ & $\mathrm{Y}=53.9600+1.5020 \mathrm{x}-0.0620 \mathrm{x}^{2^{*}}$ & 0.97 \\
Soybean & $54.3 \mathrm{a}$ & $68.0 \mathrm{a}$ & $69.5 \mathrm{a}$ & $70.2 \mathrm{a}$ & $\mathrm{Y}=54.8700+2.9340 \mathrm{x}-0.1300 \mathrm{x}^{2 *}$ & 0.96 \\
Canola & $53.5 \mathrm{a}$ & $58.7 \mathrm{c}$ & $59.8 \mathrm{c}$ & $62.0 \mathrm{~b}$ & & $\mathrm{Y}=54.5100+0.5320 \mathrm{x}^{*}$ & 0.90 \\
CV $(\%)$ & $\ldots \ldots \ldots \ldots \ldots \ldots . .1 .52 \ldots \ldots \ldots \ldots \ldots \ldots$. & & & \\
\hline
\end{tabular}

Means followed by different letters, lower case in the columns (additive), are significantly different by Tukey's test (P<0.05). *significant at 5\% level.

Source: Elaboration of the authors.

In relation to the additives within each level, at the level zero, the digestibility was similar among the meals. At the levels 5 and $10 \%$, there was a significant effect for all meals, with the lowest digestibility found for the cotton meal (Table 5). At $15 \%$, the soybean meal had the highest digestibility, with increase of 17.0; 11.7 and 13.2 in relation to the cotton, sunflower and canola meals, respectively, proving to be an excellent option of additive in tropical grass silage, by containing high protein and energy content. According to Jobim et al. (2010) the soybean can represent an option to be employed in the ensiling process, besides having an unquestionable nutritional value.

\section{Conclusion}

The oleaginous meals from biodiesel industry are indicated as additives for ensiling Piata palisadegrass, by improving the qualitative, nutritional and fermentative characteristics of the Piata palisadegrass silage. It is recommended the addition of $15 \%$ of the meals, since this level provides the best quality of silage. The soybean meal is the most effective to improve the silage quality, in comparison with the other additives. 


\section{References}

AGUIAR, R. N. S.; CRESTANA, R. F.; BALSALOBRE, M. A. A. Efeito do tamanho de partícula na composição da fração nitrogenada de silagem de capim Tanzânia. In: REUNIÃO ANUAL DA SOCIEDADE BRASILEIRA DE ZOOTECNIA, 38., Piracicaba, 2001. Anais... Piracicaba: FEALQ, 2001. p. 314-316.

AMARAL, R. C. do; BERNADES, T. F.; SIQUEIRA, G. R.; REIS, R. A. Características fermentativas e químicas de silagens de capim-Marandu produzidas com quatro pressões de compactação. Revista Brasileira de Zootecnia, Viçosa, v. 36, n. 3, p. 532-539, 2007.

ANDRADE, I. V. O.; PIRES, A. J. V.; CARVALHO, G. G. P. de; VELOSO, C. M.; BONOMO, P.; Fracionamento de proteína e carboidratos em silagens de capim-elefante contendo subprodutos agrícolas. Revista Brasileira de Zootecnia, Viçosa, v. 39, n. 11, p. 2342-2348, 2010.

ASSOCIATION OFFICIAL ANALYTICAL CHEMISTS - AOAC. Official methods of analysis. 13. ed. Washington: AOAC, 1980. 1015 p.

ASHBELL, G. Basic principles of preservation of forage, by-products and residues as silage or hay. Bet Dagan: Agricultural Research Organization, The Volcani Center. 1995. 58 p.

BERNARDINO, F. S.; GARCIA, R.; ROCHA, F. C.; SOUZA, A. L. de; PEREIRA, O. G. Produção e características do efluente e composição bromatológica da silagem de capim-elefante contendo diferentes níveis de casca de café. Revista Brasileira de Zootecnia, Viçosa, v. 34, n. 6, p. 2185-2191, 2005.

BRITO, A. F.; GONÇALVES, L. C.; RODRIGUES, J. A. S.; ROCHA JUNIOR, V. R.; RODRIGUEZ, N. M.; BORGES, I. Avaliação da silagem de sete genótipos de sorgo [(Sorghum bicolor (L) Moench)]. II. Padrão de fermentação. Arquivo Brasileiro de Medicina Veterinária e Zootecnia, Belo Horizonte, v. 52, n. 5 p. 491-497, 2000.

CARVALHO, G. G. P.; GARCIA, R.; PIRES, A. J. V.; PEREIRA, O. G.; FERNANDES, F. E. P.; OBEID, J. A.; CARVALHO, B. M. A. Fracionamento de carboidratos de silagem de capim-elefante emurchecido ou com farelo de cacau. Revista Brasileira de Zootecnia, Viçosa, v. 36, n. 4, p. 1000-1005, 2007. Suplemento.

CARVALHO, G. G. P.; GARCIA, R.; PIRES, A. J. V.; PEREIRA, O. G.; FERNANDES, F. E. P.; CARVALHO, B. M. A. Características fermentativas de silagens de capim-elefante emurchecido ou com adição de farelo de cacau. Arquivo Brasileiro de Medicina Veterinária e Zootecnia, Belo Horizonte, v. 60, n. 1, p. 234-242, 2008.
CHANDLER, P. Energy prediction of feeds by forage testing explorer. Feedstuffs, Bloomington, v. 62, n. 36, p. 1-12, 1990.

COSTA, K. A. P.; ASSIS, R. L.; GUIMARÃES, K. C.; SEVERIANO, E. C.; ASSIS NETO, J. M.; CRUNIVEL, W. S.; GARCIA J. F.; SANTOS, N. F. Silage quality of Brachiaria brizantha cultivars ensiled with different levels of millet meal. Arquivo Brasileiro de Medicina Veterinária e Zootecnia, Belo Horizonte, v. 63, n. 1, p. 188-195, 2011.

EMBRAPA GADO DE CORTE. Empresa Brasileira de Pesquisa Agropecuária. "Capim-piatã” homenageia povo indígena Tupi Guarani. Campo Grande: Informativo Piatã, 2008.

EVANGELISTA, A. R.; ABREU, J. G. de; AMARAL, P. N. C. do; PEREIRA, R. C.; SALVADOR, F. M.; SANTANA, R. A. V. Produção de silagem de capimmarandu (Brachiaria brizantha stapf cv. Marandu) com e sem emurchecimento. Ciência e Agrotecnologia, Lavras, v. 28, n. 2 , p. $443-449,2004$.

FERNANDES, L. O.; REIS, R. A.; RODRIGUES, L. R. A.; LEDIC, I. L.; MANZAN, R. J. Qualidade do feno de braquiária decumbens stapf. submetido ao tratamento com amônia anidra ou uréia. Revista Brasileira de Zootecnia, Viçosa, v. 31, n. 3, p. 1325-1332, 2002.

FERREIRA, D. F. Análises estatísticas por meio do Sisvar para Windows versão 4.0. In: REUNIÃO ANUAL DA REGIÃO BRASILEIRA DA SOCIEDADE INTERNACIONAL DE BIOMETRIA, 45., 2000, São Carlos. Anais... São Carlos: UFSCar, 2000. p. 255-258.

GONÇALVES, J. S.; NEIVA, J. N. M.; OLIVEIRA FILHO, G. S. de; LOBO, R. N. B. Valor nutritivo de silagens de capim elefante (Pennisetum purpureumShum) e Brachiaria decumbens contendo pedúnculo de caju (Annacardium occidentale L.) desidratado. Ciência Agronômica, Fortaleza, v. 38, n. 2, p. 204-209, 2007.

HENDERSON, N. Silage additives. Journal Animal Feed Science and Technology, Amsterdam, v. 45, n. 1, p. 35-56, 1993.

HUNT, C. W.; KEZAR, W.; HINMAN, D. D.; COMES, J. J.; LOESCHE, J. A.; MOEN, T. Effects of hybrid and ensiling with and without a microbial inoculant on the nutricional characteristics of whole-plant corn. Journal of Animal Science, Champaign, v. 71, n. 1, p. 38-43, 1993.

JOBIM, C. C.; CALIXTO JUNIOR, M.; BUMBIERIS JÚNIOR, V. H.; OLIVEIRA, F. C. L. de. Composição química e qualidade de conservação de silagens de grãos 
de milho (Zea mays L.) com diferentes níveis de grãos de soja (Glycine max Merril). Semina: Ciências Agrárias, Londrina, v. 31, n. 3, p. 773-782, 2010.

JOBIM, C. C.; NUSSIO, L. G.; REIS, R. A.; SCHMIDT, P. Avanços metodológicos na avaliação da qualidade da forragem conservada. Revista Brasileira de Zootecnia, Viçosa, v. 36, p. 101-119, 2007. Suplemento.

LEONEL, F. de P.; PEREIRA, J. C.; COSTA, M. G.; MARCO JUNIOR, P. de; SILVA, C. J. da; LARA, L. A. Consórcio capim-braquiária e milho: comportamento produtivo das culturas e características nutricionais e qualitativas das silagens. Revista Brasileira de Zootecnia, Viçosa, v. 38, n. 1, p. 166-176. 2009.

LIMA, L. G. de; NUSSIO, L.G.; GONÇALVES, J. R. S.; SIMAS, J. M. C. de; PIRES, A. V.; SANTOS, F. A. P. Fontes de amido e proteína para vacas leiteiras em dietas à base de capim-elefante. Scientia Agricola, Piracicaba, v. 59, n. 1, p. 19-27, 2002.

MARANHÃO, C. M. de A.; SILVA, C. C. F. da; BONOMO, P.; PIRES, A. J. V. Produção e composição químico-bromatológica de duas cultivares de braquiárias adubadas com nitrogênio e sua relação com o índice SPAD. Acta Scientiarum, Animal Sciences, Maringá, v. 31, n. 2, p. 117-122, 2009.

McDONALD, P.; HENDERSON, A. R.; HERON, S. J. E. The biochemistry of silage. 2. ed. Marlow: Chalcombe Pub, 1991. 340 p.

NATIONAL RESEARCH COUNCIL - NRC. Nutrient requirements of dairy cattle. 7. ed. rev. Washington, D.C.: $2001.381 \mathrm{p}$.

NUSSIO, L. G.; MANZANO, R. P.; PEDREIRA, C. G. S. Valor alimentício em plantas do gênero Cynodon. In: SIMPÓSIO SOBRE MANEJO DA PASAGEM, 15., 1998, Piracicaba. Anais... Piracicaba: FEALQ, 1998. p. 203-242.

NUSSIO, L. G.; SIMAS, J. E. C.; LIMA, M. L. M. Determinação do ponto de maturidade ideal para colheita do milho para silagem. In: NUSSIO, L. G.; ZOPOLLATO, M.; MOURA, J. C. (Ed.). Milho para a silagem. Piracicaba: FEALQ, 2001. p. 11-26.

OLIVEIRA, L. S.; PEREIRA, L. G. R.; AZEVÊDO, J. A. G.; PEDREIRA, M. dos S.; LOURES, D. R. S.; BOMFIM, M. A. D.; BARREIROS, D. C.; BRITO, R. L. L. de. Caracterização nutricional de silagens do coproduto da pupunha. Revista Brasileira de Saúde e Produção Animal, Salvador, v. 11, n. 2, p. 426-439, 2010.

OLIVEIRA, R. L.; RIBEIRO, O. L.; BAGALDO, A. R.; LIMA, L. dos S.; BORJA, M. S.; CORREIA, B. R.; COSTA, J. B.; LEÃO, A. G. Torta de dendê oriunda da produção do biodiesel na ensilagem de capim-massai.
Revista Brasileira de Saúde e Produção Animal, Salvador, v. 12, n. 4, p. 881-892, 2011.

PAZIANI, S. de F.; NUSSIO, L. G.; PIRES, A. V.; RIBEIRO, J. L.; ZOPOLLATTO, M.; SCHMIDT, P. Efeito do emurchecimento e do inoculante bacteriano sobre a qualidade da silagem de capim-tanzânia e o desempenho de novilhas. Acta Scientiarum Animal Science, Maringá, v. 28, n. 4, p. 393-400, 2006.

REGÔ, A. C.; CÂNDIDO, M. J. D.; PEREIRA, E. S.; FEITOSA, J. V.; RÊGO, M. M. T. Degradação de silagens de capim-elefante contendo subproduto do Urucum. Revista Ciência Agronômica, Fortaleza, v. 41, n. 3, p. 482-489, 2010.

REZENDE, A. V.; RODRIGUES, R.; BARCELOS, A. F.; CASLI, A. O.; VALERIANO, A. R.; MEDEIROS, L. T. Qualidade bromatológica das silagens de capimelefante aditivadas com raspa de batata. Ciência $e$ Agrotecnologia, Lavras, v. 32, n. 2, p. 604-610, 2008.

REZENDE, A. V.; EVANGELISTA, A. R.; BARCELOS, A. F.; SIQUEIRA, G. F.; SANTOS, R. V.; MAZO, M. S. Efeito da mistura da planta de girassol (Helianthus annuus L. ), durante a ensilagem do capim-elefante (Pennisetum purpureum Schum.) no valor nutritivo da silagem. Revista Brasileira de Zootecnia, Viçosa, v. 31, n. 5, p. 1938-1943, 2002.

RIBEIRO, R. D. X.; OLIVEIRA, R. L.; BAGALDO, A. R.; FARIA, E. F. S.; GARCEZ NETO, A. F.; SILVA, T. M.; BORJA, M. S.; CARDOSO NETO, B. M. Capimtanzânia ensilado com níveis de farelo de trigo. Revista Brasileira de Saúde e Produção Animal, Salvador, v. 9, n. 4, p. 631-640, 2008.

RODRIGUES, P. H. M.; LOBO, J. R.; SILVA, E. J. A. da; BORGES, L. F. O.; MEYER, P. M.; DEMARCHI, J. J. A. de. A. Efeito da inclusão de polpa cítrica peletizada na confecção de silagem de capim-elefante (Pennisetum purpureum, Schum.). Revista Brasileira de Zootecnia, Viçosa, v. 36, n. 6, p. 1751-1760, 2007.

SANTOS, M. V. F.; GÓMEZ CASTRO, A. G.; PEREA, J. M.; GARCÍA, A.; GUIM, A.; PÉREZ HERNÁNDEZ, M. Fatores que afetam o valor nutritivo das silagens de forrageiras tropicais. Archivos de Zootecnia, Córdoba, v. 59, p. 25-43, 2010.

SILVA, D. J.; QUEIROZ, A. C. Análise de alimentos: métodos químicos e biológicos. 3. ed. Viçosa: Imprensa Universitária da UFV, 2002. 235 p.

SNIFFEN, C. J.; O'CONNOR, J. D.; VAN SOEST, P. J.; FOX, D. G.; RUSSELL, J. B. A net carbohydrate and protein system for evaluating cattle diets: carbohydrate and protein availability. Journal of Animal Science, Champaign, v. 70, n. 1, p. 3562-3577, 1992. 
TEIXEIRA, F. A.; VELOSO, C. M.; PIRES, A. V.; SILVA, F. F.; NASCIMENTO, P. V. N. Perdas na ensilagem de capim-elefante aditivado com farelo de cacau e canade-açúcar. Arquivo Brasileiro de Medicina Veterinária e Zootecnia, Belo Horizonte, v. 60, n. 1, p. 227-233, 2008.

TILLEY. J. M. A.; TERRY, R. A. A two stage technique for in vitro digestion of forages crops. Journal of the British Grassland Society, Oxford, v. 18, n. 2, p. 104111, 1963.

TOMICH, T. R.; RODRIGUES, J. A. S.; TOMICH, R. G. P.; GONÇALVES, L. C.; BORGES, I. Potencial forrageiro de híbridos de sorgo com capim-sudão. Arquivos Brasileiros de Medicina Veterinária e Zootecnia, Belo Horizonte, v. 56, n. 2, p. 258-263, 2004.
VAN SOEST, P. J. Nutritional ecology of the ruminant. 2. ed. Ithaca: Cornell University Press, 1994. 476 p.

ZANINE, A. de M.; SANTOS, E. M.; DÓREA, J. R. R.; DANTAS, P. A. de S.; DA SILVA, T. C.; PEREIRA, O. G. Evaluation of elephant grass silage with the addition of cassava scrapings. Revista Brasileira de Zootenia, Viçosa, v. 39, n. 12, p. 2611-2616, 2010. 